\title{
SOME STUDIES ON THE EFFECT OF DIFFERENT STRAINS OF EIMERIA SPP. IN QUAILS EXPERIMENTALLY INFECTED WITH E. COLI.
}

\author{
Entessar, A. Ahmed Arafa and Soad A. Nasef \\ Department of Avian Diseases, Animal Health Research Institute. \\ Ministry of Agriculture, Dokki, Egypt.
}

\begin{abstract}
The interactive effect of E. coli and intestinal coccidiosis infections in quails broilers was studied. Single and dual orally inoculations were assessed in 6 groups of 25 quails chicks each. Mortality rate in group infected with Eimeria only was 24\%; in group infected with Eimeria before E. coli was $28 \%$ while in group infected with E.coli and Eimeria at the same time was 32\%,otherwise no mortalities observed in other tested groups. The total oocyst output and lesion score were high and severe in quail chicks infected with intestinal coccidiosis alone or with E. coli prior to coccidial infection. Low oocyst output and moderate intestinal lesion score were noticed in quail chicks inoculated with $E$. coli prior to or together with intestinal coccidiosis infection. Statistically using LSD, there was a significant decrease in body weight gain in all tested groups infected either with E. coli or intestinal Eimeria spp. or with both pathogens. These results suggested a synergistic action between E. coli and intestinal Eimeria spp. in producing gross lesions.
\end{abstract}

\section{INTRODUCTION}

$\boldsymbol{E}$. coli infection in quails has been associated with a variety of disease conditions including acute septicaemia, haemorrhagic enteritis, salpingitis, air saculitis, pericarditis and chronic synovitis in joints (Melamed et al., 1991). 
Quails of all ages are susceptible to diseases, caused by Escherichia coli and significant economic loss is increased due to morbidity, mortality, cost of treatment and condemnations of infected quails (Hammouda, 1992). In layers farms E. coli infections revealed low level of egg production (Franches et al. ,1995).

An outbreak of septicaemia was caused by 0:165 of serogroup of E. coli in Japanese quails (Arenas et al., 1999). Coligranuloma was reached in Japanese quails in Brazil. The disease caused an $85 \%$ drop in egg production and $15 \%$ mortalities (Da Silva et al., 1989).

Coccidiosis is one of the most important parasitic disease infecting quails as other poultry (Shane, 1985). It is caused by Eimeria species which infecting primarily the intestinal tract of the susceptible host, They seriously impairing food utilization and the growth of infected life stock and poultry (Rose and Hesketh, 1991). Susceptibility of birds to bacterial infection was increased due to intestinal lesions which produced by coccidian infection (Arakawa et al., 1981 and Boba et al. 1982). Yatuserich (1982) observed that $E$. coli and Eimeria species are synergistic pathogens.

Nakamura et al. (1990) reported interactive effect of $\boldsymbol{E}$. tenella and $\boldsymbol{E}$. coli infection in chicken and noticed that caecal lesions induced by E. tenella were more severe in chickens which were infected by both.

Therefore in this study we try to study the interaction between intestinal coccidiosis and E. coli infections in quails broiler.

\section{MATERIALS AND METHODS}

\section{E. coli strain :}

A strain of Escherichia coli that previously isolated from Japanese quails and identified morphologically, biochemically and serologically as E. coli O:165 according to Lennette (1980) and McFaddin (1984), was used to infect quails chicks orally with $10^{8} \mathrm{CFU}$ per 21-day old chicks. 


\section{Coccidia strain :}

A field strain of quails intestinal coccidiosis was used. The infected dose was $6 \times 10^{4}$ sporulated oocysts / quail chick per os.

\section{Experimental design :}

A total of one hundred and seventy Japanese quails were used for this study. They were raised and fed a balanced unmedicated ration. A twenty quails chicks were slaughtered and subjected for laboratory examination to be sure that they were free from coccidian and E. coli infections. Quails chicks were divided into six groups weighted and placed in a separate cages (twenty five quails per cage). Group I was kept as non infected group. Group II, the quails chicks were inoculated with 6 X $10^{4}$ sporulated oocysts per quail chicks through oral route on day twenty one of quails age body weights were recorded at 20 day old and weekly for five weeks. Group III, the quails were infected orally with 107 CFU of E. coli O:165 on day twenty one of age. Group IV, the members were infected orally on day twenty one with $6 \times 10^{4}$ sporulated oocyst per chicks and after fifty hours they received $10^{7} \mathrm{CFU}$ of E. coli O:165. Group V, they infected firstly with $10^{7} \mathrm{CFU}$ of E. coli O:165 on day twenty one and after 50 hours they inoculated with $6 \times 10^{4}$ sporulated oocyst per os. Group VI, the quails chicks were infected on day twenty one with $10^{7} \mathrm{CFU}$ of E. coli O:165 and $6 \times 10^{4}$ sporulated oocyst at the same time. All quails chicks were kept for five weeks. Five birds were slaughtered every five days and subjected to bacterial and parasitic examination. The parameters used for evaluation of severity of coccidian infection were mortality percentage, faecal scores (Morehouse and Barny, 1970) and total oocysts output / gm faeces using McMaster count chamber by Long and Rowell (1975). Isolation and identification of E. coli was done according to McFaddin (1984).

Statistical analysis: Data, obtained, were statistically analysed, using the analysis of variance (ANOVA) and comparing groups was performed using the least significant difference (LSD) at $\mathrm{P}<0.05$ according to Petrie and Watson (1999) and computerized using SPSS 11 (2001). 


\section{RESULTS AND DISCUSSION}

Concurrent infections of poultry species with coccidiosis and bacterial or viral disease was a major problem facing poultry industry. $\boldsymbol{E}$. coli is a normal inhabitant of intestinal tract of quails and it contaminates the environment in quails farms that facilitate the reinfection of quails with E. coli (Morishita et al. , 1999 and Samour, 2000).

Intestinal tract is the predilection seat of $\boldsymbol{E}$. coli serotypes and Eimeria species. In the present study, there was diarrhoea in groups II, III, IV, V and VI. This diarrhoea was bloody in group II and IV. There was naked decrease in total body weight in groups IV, V and VI which inoculated with $\boldsymbol{E}$. coli after or before or at the same time of Eimeria infection. These results were in agreement with Nakamura et al. (1990) who reported that $\boldsymbol{E}$. coli or Eimeria infection produce significantly decrease in body weight as compared with control group. These results might be due to damage produced in intestinal mucosa and subm-ucosa which impaired digestion and absorption through the intestinal wall (Gast and Beard, 1992 and Awadalla and Nasef, 1998).

The highest mortality rate was recorded in group VI which infected with $\boldsymbol{E}$. coli and Eimeria spp. at the same time. These results were in agreement with those reported by Awadalla and Nasef (1998).

Regarding to total oocyst output was significantly low in quails inoculated with $\boldsymbol{E}$. coli at the same time with Eimeria (group VI) and in group V which inoculated with $\boldsymbol{E}$. coli prior to coccidia spp. (group II) only. The highest was recorded in group IV which inoculated with Eimeria spp. before $\boldsymbol{E}$. coli organism. This can be attributed to the fact that competition between the two pathogens was established and one of them which inoculated first could colonize itself in the epithelial lining 
of the intestine and prevent multiplication of the several pathogen (Awadalla and Nasef, 1998 ). Dominick and Jensen (1984) reported that oral inoculation of turkey with E. coli resulted in extensive colonization of intestinal lesions expressed as gross score (GLS) induced by intestinal coccidial spp. infection alone and prior to $\boldsymbol{E}$. coli inoculation were more severe than that GLS induced by E.coli inoculation prior to or at the same time with intestinal and caecal Eimeria spp.Hegde et al.(1969) established that the presence of secondary microbial invador is not essential for Eimeria intesti-nals either to establish itself or to induce pathological changes. The result was same as observed by Tambur et al. (1997) who mentioned that, coccidiosis was the main cause of the pathological change and $\boldsymbol{E}$. coli was only a secondary infection. On the other hand, Nakamura et al. (1990) reported that, oral inocu-lation of $\boldsymbol{E}$. coli had on effect an the severity of caecal and intestinal lesion caused by E. intestinais.

Table (1): Mortalities in quails broilers infected with E. coli O:165 and field strain of intestinal quails Eimeria.

\begin{tabular}{|l||c||c||c||}
\hline \multicolumn{1}{|c|}{ Groups } & No. of birds & No. of death & $\%$ \\
\hline \hline Group (I) control negative & 25 & 0 & $0 \%$ \\
\hline Group (II) Eimeria only & 25 & 6 & $24 \%$ \\
\hline Group (III) E. coli O:165 only & 25 & 0 & $0 \%$ \\
\hline Group (IV) Eimeria before E. coli & 25 & 7 & $28 \%$ \\
\hline Group (V) E. coli before Eimeria & 25 & 0 & $0 \%$ \\
\hline Group (VI) E. coli and Eimeria at the same time & 25 & 8 & $32 \%$ \\
\hline
\end{tabular}


Entessar, A. Ahmed Arafa \& Soad A. Nasef.

Table (2): Percentage of E. coli reisolation from experimentally infected quails at day $5^{\text {th }}, 10^{\text {th }}, 15^{\text {th }}$ post infection.

\begin{tabular}{|c|c|c|c|}
\hline Groups No. & $\begin{array}{c}5 \text { days } \\
\text { post } \\
\text { infection }\end{array}$ & $\begin{array}{c}10 \text { days } \\
\text { post } \\
\text { infection }\end{array}$ & $\begin{array}{c}15 \text { days } \\
\text { post } \\
\text { infection }\end{array}$ \\
\hline Group (I) control negative & $0 \%$ & $0 \%$ & $0 \%$ \\
\hline Group (II) Eimeria only & $0 \%$ & $0 \%$ & $0 \%$ \\
\hline Group (III) E. coli only & $100 \%$ & $60 \%$ & $20 \%$ \\
\hline Group (IV) Eimeria before E. coli & $0 \%$ & $40 \%$ & $40 \%$ \\
\hline Group (V) E. coli before Eimeria & $100 \%$ & $60 \%$ & $20 \%$ \\
\hline Group (VI) E. coli and Eimeria at the same time & $80 \%$ & $20 \%$ & $20 \%$ \\
\hline
\end{tabular}

Table(3):Influence of E. coli and intestinal Eimeria species infection on quails.

\begin{tabular}{|c|c|c|c|c|}
\hline \multirow[b]{2}{*}{ Groups No. } & \multirow{2}{*}{$\begin{array}{l}\text { Oocyst } \\
\text { output/gm } \\
\text { faeces }\end{array}$} & \multirow{2}{*}{$\begin{array}{c}\text { Intestinal } \\
\text { Eimeria } \\
\text { score }\end{array}$} & \multicolumn{2}{|c|}{ Protection against lesion } \\
\hline & & & $\begin{array}{l}\text { Lesion } \\
\text { score }\end{array}$ & Protection \\
\hline Group (I) control negative & Negative & Negative & Negative & Negative \\
\hline Group (II) Eimeria only & 19500 & $4.6 \pm 0.9$ & 90 & 10 \\
\hline Group (III) E. coli only & Negative & Negative & Negative & Negative \\
\hline Group (IV) Eimeria before E. coli & 15400 & $3.8 \pm 0.7$ & 80 & 20 \\
\hline Group (V) E. coli before Eimeria & 63500 & $1.9 \pm 0.5$ & 50 & 50 \\
\hline $\begin{array}{l}\text { Group (VI) E. coli and Eimeria at } \\
\text { the same time }\end{array}$ & 54900 & $1.7 \pm 0.3$ & 40 & 60 \\
\hline
\end{tabular}

$\overline{\overline{\text { Kafr El-Sheikh Vet. Med. J. Vol. } 2 \text { No. } 1 \text { (2004) }}}$ 
$\overline{\text { Kafr El-Sheikh Vet. Med. J. Vol. } 2 \text { No. } 1 \text { (2004) }}$ 


\section{REFERENCES}

- Arakawa, A. ; Baba, E. and Fukata, T. (1981): Eimeria tenella infection enhances Salmonella typhimurium infection in chickens. Poult. Sci., 60 : 2203-2209.

- Arenas,A.; Vicente, S. ; Luque, I. ; Gomez-Villamandos, J. C. ; Astorga, R. ; Maldonado, A. and Tarradas, C. (1999): Outbreak of septicaemic colibacillosis in Japanese quails (Coturnix coturnix japonica). Zentralbl. Vet. (B), 46 (6) : 399 - 404.

- Awadalla, S. F. and Nasef, S. A. (1998): Relationship between E. tenella, dietary, lactose, anaerobic caecal flora on Salmonella enteritidis infection in broilers. Suez Canal Vet. Med. J., 1 (2) : 223 -231 .

- Baba, E. ; Fukata, T. and Arakawa, A. (1982): Establishment and persist-ence of Salmonella typhimurium infection stimulated by Eimeria tenella in chicken. Res. Vet. Sc., 33 : 95 - 98.

- Da Silva, P. L. ; Coelho, H. E. ; Ribeiro, S. C. ; Oliveira, P. R. (1989): Occurrence of coligranulomatosis in Coturnix quail in Uberlandia, Minas gErais, Brazil. Avian Dis., 33 (3) : 590 - 595.

- Domimick, M. A. and Jensen, A. E. (1984): Colonization and persistence of Escherichia coli in axenic and non axenic turkeys. Am. J. Vet. Res., 45 : 2331 - 2335.

- Franchesi, M. De. ; Viora, S. and Barrios, H. (1995): Escherichia coli infections in layer quails.Rivistas de.Med.Vet.Buenos Aires, 16 (6):416- 420.

- Gast,R. K.and Beard, C. W. (1992): Evaluation of a chick mortality model predicting the consequences of Salmonella enteritidis infection in laying hens. Poult. Sci., $71: 281-287$.

- Hammouda, A. M. (1992): Studies on the bacteril causes of early quails mortalities.M.V.Sc.,A Thesis (Microbiology),Fac. Vet. Med., Zagazig Univ.

- Hegde, K. S. ; Reid, W. M. ; Johnson, J. and Womack, H. E. (1969): Pathogenicity of Eimeria brunette in bacteria free and conventional chicks. J. Parasitol., 55 (2) : 402 - 405.

$\overline{\bar{K} \text { Kafr El-Sheikh Vet. Med. J. Vol. } 2 \text { No. } 1 \text { (2004) }}$ 
- Lennette, E. H. (1980): Manual of Clinical Microbiology. $3^{\text {rd }}$ ed. American Society for Microbiology, Washington, D.C.

- Long, P. L. and Rowell, J. G. ( 1975 ): Sampling broiler house litter for coccidial oocysts. R. Poult. Sci., $16: 583-592$.

- McFaddin, J. F. (1984): Biochemical tests for identification of medical bacteria. $2^{\text {nd }}$ ed. Williams and Wilkins, Baltimore, M.D.

- Melamed, D.; Leitner,G.and Heller, E. D.(1991): A vaccine against avian colibacillosis based on ultrasonic inactivation of Escherichia coli.Avian Dis., 35 : 17 - 22.

- Morehouse, N. F. and Barny, R. R. (1970): Coccidiosis evaluation of cocciostates by mortality, weight gain and fecal scores. Expl. Parasit., $28: 25$ - 29.

- Nakamura, K. ; Isobe, T. and Narita,M.(1990): Dual infection of Eimeria tenella and E. coli in chickens. Res. Vet. Sci., 49 : $125-$ 126.

- Petrie, A. and Watson, P. (1999): "Statistics for Veterinary and Animal Science." $1^{\text {st }}$ Ed., pp. 90-99, 110-115, The Blackwell Science Ltd, United Kingdom.

- Rose, M. E. and Hesketh, P. C. (1991): Eimeria tenella : Localizing of the sporozoites in common of the domestic fowl. Parasitology, 102: $317-324$.

- Shane, S. M. (1985): Common diseases and other conditions off quails. Avian Exotic Practice,.., 2 (3) : 13 - 23.

- SPSS 11 (2001): "SPSS for windows Release 11.0.1.27 Oct. 1999." Standard Version, Copyright SPSS Inc., 1989-2001, All Rights Reserved, Copyright ${ }^{\circledR}$ SPSS Inc. 
- Tambur, Z. ; Kulisic, Z. ; Vetic, V. and Maliceric, Z.(1997): Pathological changes in rabbits experimentally infected with intestinal coccidia. Veterim-arski Glasnik., 51 (5-6) : 253 - 260.

- Yatuserich, A. I. (1982): The parasites gensosis of Eimeria and E. coli in chicks. Kishnge Prosteishie, 143 - 146. 